Case Report

\title{
Unicornuate Uterus with Rudimentary Horn and Complicated with Endometriosis
}

\section{Uterus Unikornuasi dengan Kornu Rudimenter dan Endometriosis}

\author{
Liva Wijaya, Junizaf, Shirley Anggraini, Djoni Nurung, Prijono, Punarbawa \\ Subdivision Urogynecology Obstetric and Gynecology \\ Department of Obstetrics and Gynecology/ \\ Dr. Cipto Mangunkusumo Hospital \\ Jakarta
}

\begin{abstract}
Objective: To report the congenital abnormalities of müllerian duct and review its literature.

Methods: Case report.

Case: A sixteen years old unmarried woman came to our policlinic with chief complain of cyclical abdominal pain (VAS 6). She had regular menstruation. In other hospital, she had diagnosed as suffering from ovarian tumor. Our examination showed that the uterus was unicornuate with rudimentary horn. We did explorative laparotomy. We took out the left cornu and left salpingoophorectomy due to hematosalphing and endometrial cyst. The Visual analogue score after surgery was reduced until VAS 2.

Conclusion: Congenital abnormalities of the müllerian ducts are relatively common. Comprehensive examination can diagnose this abnormality earlier, thus intervention can be given as soon as possible.

[Indones J Obstet Gynecol 2013; 1-4: 215-8]

Keywords: abnormalities müllerian ductus, endometriosis
\end{abstract}

\begin{abstract}
Abstrak
Tujuan: Untuk melaporkan kelainan kongenital pada duktus müller dan mereview beberapa literatur.

Metode: Laporan kasus.

Kasus: Nona 16 tahun mengeluhkan nyeri perut siklik (VAS 6). Pasien memiliki mestruasi teratur. Di Rumah sakit luar, pasien didiagnosis sebagi tumor ovarium. Pemeriksaan kami menyimpulkan bahwa pasien ini memiliki kelainan uterus dengan 1 kornu lainnya rudimenter. Kami melakukan laparotomi eksplorasi, mengangkat kornu yang rudimenter, tuba, dan ovarium yang berhubungan karena membesar akibat endometriosis. Skala nyeri setelah operasi berkurang menjadi VAS 2.

Kesimpulan: Kelainan bawaan pada duktus müller sangatlah umum. Pemeriksaan yang menyeluruh dapat mendiagnosis kelainan ini lebih awal dan intervensi dapat dilakukan sesegera mungkin.

[Maj Obstet Ginekol Indones 2013; 1-4: 215-8]

Kata kunci: endometriosis, kelainan duktus müllerian
\end{abstract}

Correspondence: Liva Wijaya, Department of Obstetrics and Gynecology Faculty of Medicine University of Indonesia/Dr. Cipto Mangunkusumo Hospital Jakarta Pusat, phone: 08122055012, email: bugmd13@yahoo.com

\section{INTRODUCTION}

Congenital abnormalities of the müllerian ducts are relatively common, occurring in $7 \%$ to $10 \%$ of all women. It contributes to the problems of infertility, recurrent pregnancy loss, and poor pregnancy outcomes that occur in approximately $25 \%$ of women with uterine anomalies. Unicornuate uterus with a rudimentary horn is a rare Müllerian anomaly, with an incidence of $0.06 \%$. A partial or complete lack of development of one Müllerian duct between the $7^{\text {th }}$ and $8^{\text {th }}$ week of gestation may result in the formation of a unicornuate uterus. The functioning unicornuate uterus may or may not be associated with a rudimentary uterine horn. Seventy-five to ninety percent of unicornuate uteri with rudimentary horns are non-communicating. The altered uterine configuration is associated with an increase in endometriosis and in obstetrical complications (early spontaneous miscarriage, ectopic pregnancy, abnormal presentations, intrauterine growth retardation, and premature labor). Implantation in the rudimentary horn is followed by a very high rate of pregnancy wastage or tubal pregnancies. A rudimentary horn can also be the cause of chronic pain, and in this case, a surgical excision is recommended. However, most rudimentary horns are asymptomatic because they are noncommunicating, and the endometrium is not functional. Approximately $40 \%$ of patients with a unicornuate uterus will have a urinary tract anomaly (usually of the kidney). Surgical reconstructive procedures do not improve obstetrical outcomes. ${ }^{1-3}$ The objective of this paper is to report our case and review its literatures. 


\section{CASE PRESENTATION}

A sixteen years old unmarried woman came to our policlinic with chief complain of cyclical abdominal pain (VAS 6) since 6 months before admission. She had regular menstruation, and each cycle has a duration of 7 to 10 days. This patient had US examination and CT scan performed out side of our hospital which revealed the presence of an ovarian cyst. She had another examination and it was revealed that she had 2 horn uterus with one cervix. Due to these two different diagnosis, she made another consultation in our hospital. On physical examination, she had normal secondary sexual sign. We found abdominal mass located on 2 finger above symphisis pubic. On inspection, we found that the vulva and urethra were normal. This patient had normal labia, normal vulva, and normal hymen. We performed vaginal ultrasound and we found that the length of the uterus was approximatelly 7-8 $\mathrm{cm}$. On rectal examination we found normal shaped uterine. We found adnexal mass in the left side approximately $7 \mathrm{~cm}$ with limited mobility. No pain was felt. On US examination we found 2 fundal with 2 uterine cavum, correspond with 2 horn uterus. No abnormality was found inside of the right horn cavity, reguler endometrium, $12 \mathrm{~mm}$, connected with normal cervical canal. Left horn cavity has an opening of $33 \times 28 \mathrm{~mm}$, with ecointernal material inside. This horn was not connected with normal cervical canal, thus we suspected that it was a rudimentary type. Right adnexa was normal, but on the left adnexa we found a cystic mass, round shaped, approximately $64 \times 52 \mathrm{~mm}$ with echointernal material suspected as hematosalping. Normal left ovary made adhesion with the distal part of hematosalphing.

Intraoperatively, after the peritoneum was opened, we found 3 cystic mass, diameter $8 \mathrm{~cm}$ from left adnexa corespond to ovarian cyst susp endometriosis cyst, $5 \mathrm{~cm}$ connected with uterus corespond to left horn, and tubuler cystic mass with diameter $3 \mathrm{~cm}$ corespond to left hydrosalphing. On palpated we found normal right horn and ovary. There were adhesion in the posterior wall of the cyst and the colon descenden, we performed adhesiolisis. We identified the left IP ligament, we clamped, cut, and sutured. We also clamped, cut and sutured the left round ligament. After we performed left salphingoophorectomy, we can see that cervix, the right tube and ovary within normal limit. We cut the left horn, and made hemostatic suture interuptedly with vicril 1 . We hang the left edge of the left cornu with left round ligament. We concluded this anomaly as Unicornuate uterus, rudimentary horn with cavity, not communicating and left endometrial cyst (confirmed by histopathology result).

\section{DISCUSSION}

A unicornuate uterus with rudimentary horn occurs as a result of failure of complete development

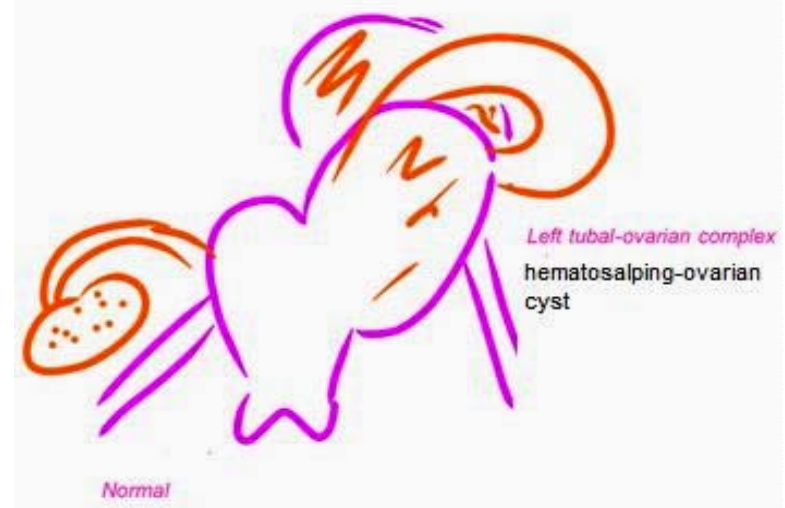

Scheme 1. Enlarged left horn, tube and adnexa due to non communicating rudimentary horn

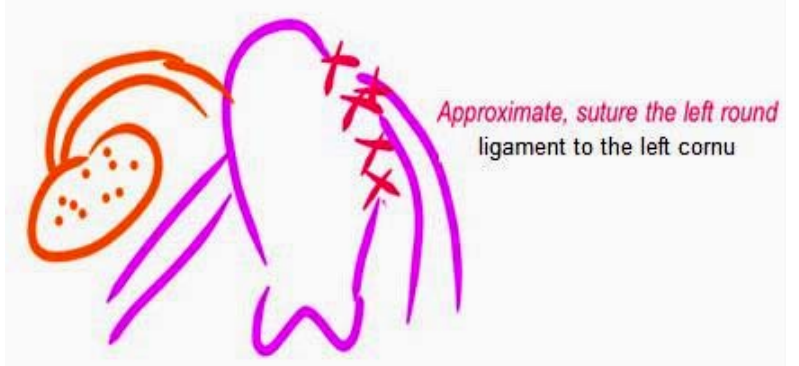

Scheme 2. Excision of left horn and left salphingoophorectomy was performed. The uterus was approximated to the round ligament.

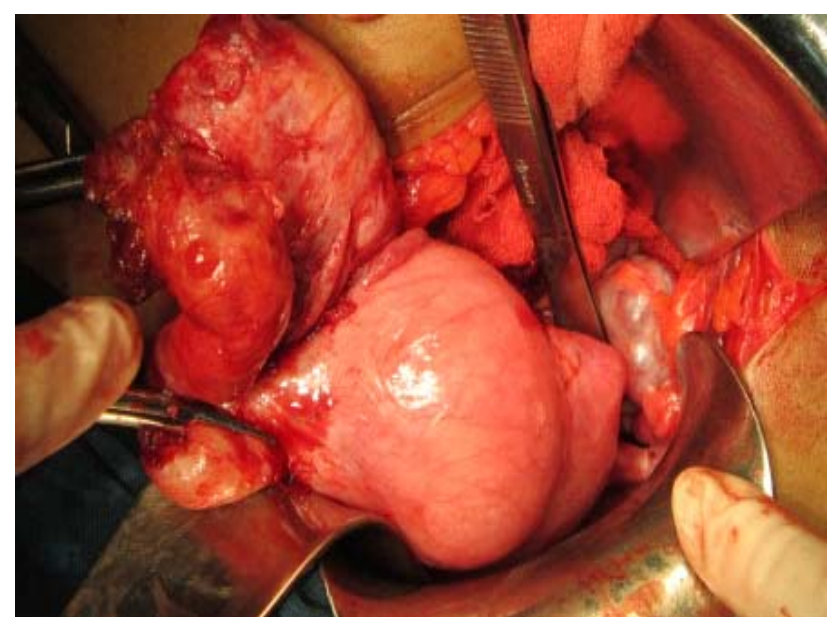

Figure 1. Normal right tube and ovary. Enlarged left horn, tube, and ovary 


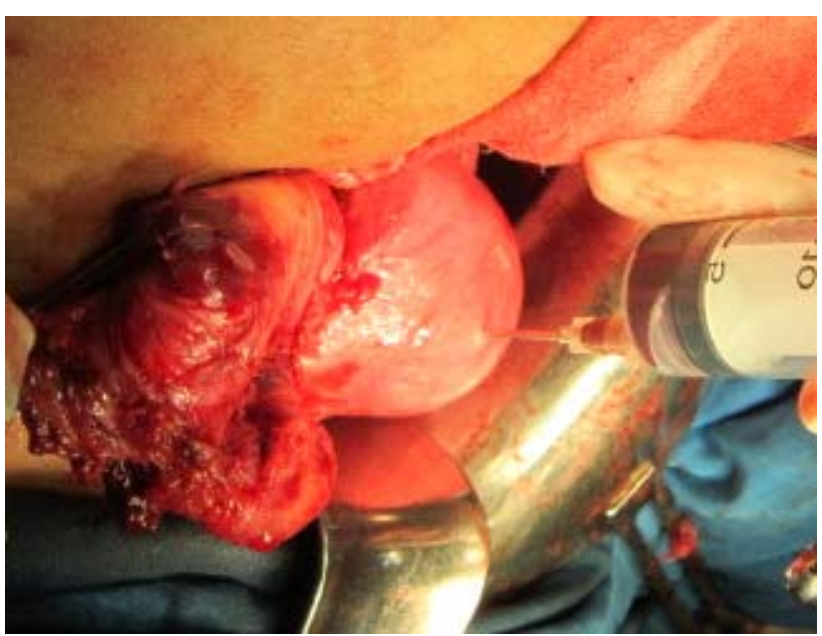

Figure 2. Aspiration of the left horn, came out brownish fluid correspond to retained blood

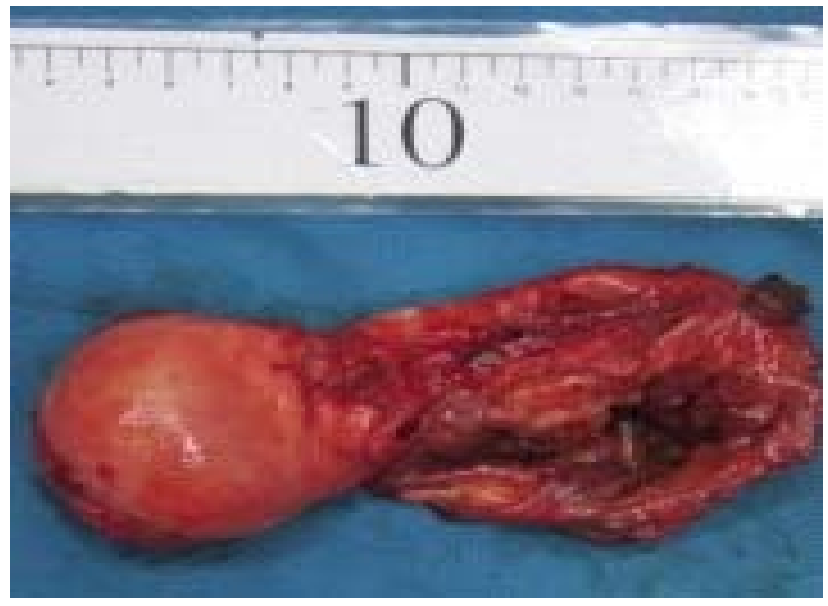

Figure 3. Enlarged left horn due to non communicating rudimentary horn

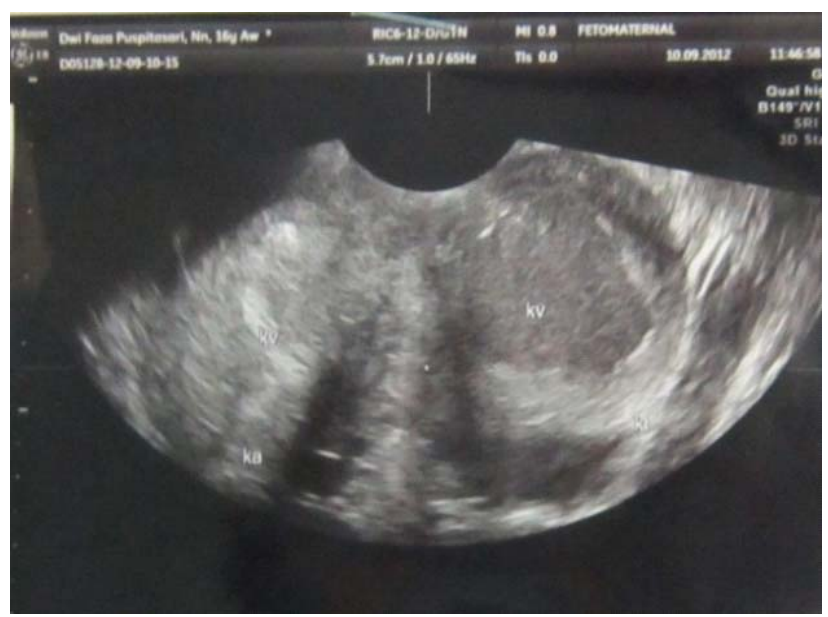

Figure 4. US examination revealed 2 uterine cavity; 1 cavity was enlarged due to retained blood

of one of the müllerian ducts and incomplete fusion with the contra lateral side. Unicornuate uterus may have either communicating or non-communi-

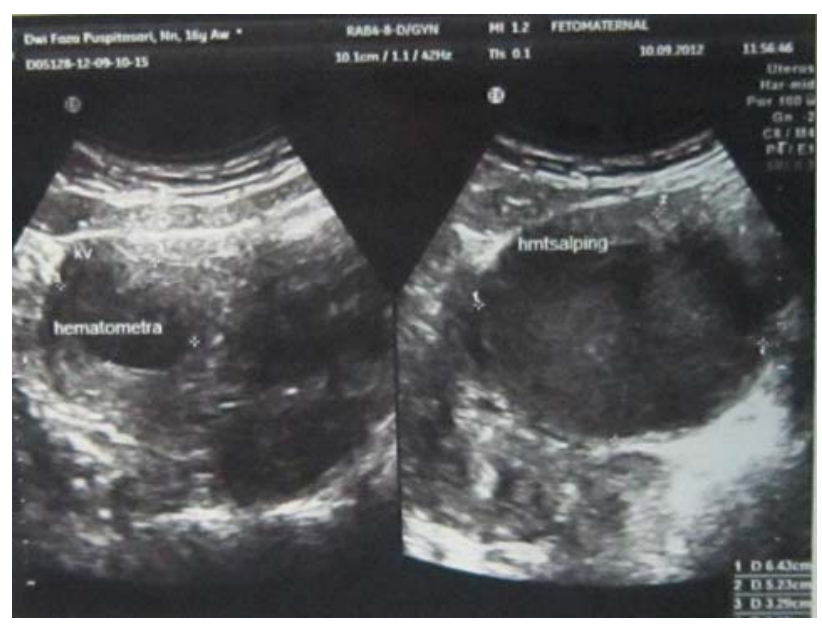

Figure 5. US examination revealed hematosalphing and hematometra

cating rudimentary horn, absent rudimentary horn or a rudimentary horn with no cavity. A unicornuate uterus is found in $0.4 \%$ of reproductive age women and is associated with endometriosis in up to $40 \%$ of cases. ${ }^{2,4}$ Although there are many theories of the pathogenesis of endometriosis, a widely accepted theory is that of retrograde menstruation, postulated by Sampson. The pathophisiology of endometriosis in this case could be from retrograde menstruation. As we know, the rate of endometriosis will increase in patient with mullerian duct anomaly. ${ }^{2}$ As in our case, endometriosis was found incidentally intraoperative.

The clinical manifestation is unspecified. If the horn is communicated with the normal cervical canal, there will be no symptoms. The asymptomatic communicated horn will be made complication like ectopic pregnancy, or acute abdomen due to rupture in the second trimester of pregnancy. Obstetric complication associated with unicornuate uteri are miscarriage in $37 \%$, preterm birth in $16 \%$, and term birth in only $45 \% .^{5}$ Cyclical pain will be felt if the horn is not communicated with the cervical. Like in this case, the patient had regular menstruation but felt cyclical pain as an effect from enlargement of the horn, tube, and adnexa.

Diagnostic modality is needed to make a diagnosis earlier. Uterine anomalies can be suspected or screened based on history taking, physical examination, hysterosalphingography and ultrasonographic evaluation. But diagnosis by these means is only succeeded in $14 \%$ of cases before these become symptomatic. In assessing a unicornuate uterus with HSG, blocked or non-communicating rudimentary horns will not be detected on film. 
Reaching a diagnosis in the pregnancy will be even more difficult. In USG, gestational sac surrounded by myometrium is seen as separated from the uterus. The USG could also show a pseudo pattern of an asymmetrical bicornuate uterus, absent visual continuity in tissue surrounding the gestational sac, uterus and cervix, which all indicate rudimentary horn pregnancy. Sensitivity of USG is $26 \%$ and it decreases along with advancing pregnancy age. In most cases, diagnosis is missed by inexperienced hand. Three dimensional USG may be used to diagnose uterine abnormalities. In this case, the abnormality was found with 2D US examination. Before admission in this hospital, she had CT scan performed, which revealed a suspected ovarian cyst.

Laparoscopy is the most accurate modality to get the diagnosis. MRI is also proven to be a useful and noninvasive tool to detect uterine anomalies. Once the diagnosis is strongly suspected, these patients should be taken up for laparoscopy or laparotomy. ${ }^{6-11}$

In review of literature, renal tract anomalies appeared to be found in $15-40 \%$ of the cases, including ectopic kidney, renal agenesis, double renal pelvis, horseshoe kidneys and unilateral medullary sponge kidney. MDA is also associated with skeletal anomalies like congenital fusion or absence of vertebra and it is seen in of $12-50 \%$ cases. An association of müllerian duct aplasia, renal aplasia and cervicothoracic somite dysplasia called MURCS has also been documented. ${ }^{12,13}$ In this case, no abnormality was found in other organs. The Visual analogue score after surgery was reduced until VAS 2.

\section{CONCLUSION}

Congenital abnormalities of the müllerian ducts are relatively common. Comprehensive examination can be diagnose this abnormality earlier and intervention can be given as soon as possible.

\section{REFERENCES}

1. Fritz Marc A, Speroff Leon. The Uterus, Clinical Gynecologic Endocrinology and Infertility, 8 ${ }^{\text {th }}$ Edition, 2011 Lippincott Williams \& Wilkins.

2. Acien P. Incidence of Müllerian defects in fertile and infertile women. Hum Reprod. 1997; 8:122.

3. Raga F, Bauset C, Remohi J, et al. Reproductive impact of congenital Müllerian anomalies. Hum Reprod. 1997; 2277:2281-312

4. Heinonen PK. Unicorunate uterus and rudimentary horn. Fertil Steril 1997; 68:224-30.

5. Liu MM. Unicornuate uterus with rudimentary horn. Int J Gynecol Obstet 1994; 44:149-53.

6. Jayasinghe Y, Rene A, Stalewski H, Grover S. The presentation and early diagnosis of the rudimentary uterine horn. Obstet Gynecol 2005; 105:1456-67.

7. Propst AM, Hill JA. Anatomic factors associated with recurrent pregnancy loss. Semin Reprod Med 2000; 18:341-50.

8. Avi Tsafir, Wathan Rojansky, Hen Yithaksela, John Moshe Gomori, Micheal Nadjar. I trimester prerupture sonographic diagnosis and confirmation by MRI. J Ultrasound Med 2005, 24:219-23

9. Daskalakis George, Pilalis Althanasios, Lyker idou Katerina, Antsaklis Aris. Rupture of noncommunicating rudimentary horn pregnancy. Obstet Gynecol 2002; 100:1108-10.

10. Goel P, Saha PK, Mehra R, Huria A. Unruptured postdated pregnancy with a live fetus in a noncommunicating rudimentary horn, Indian J Med Sci, 2007; 61, (1):23-7.

11. Jin Woo Shin, Hai Joong Kim. Case of live birth in a non communicating Rudimentary horn. J Obstet Gynecol research, 2005; 31,(4): 329-31.

12. Troiano RN, McCarthy SM. Müllerian duct anomalies: imaging and clinical issues. Radiol 2004; 233:19-34.

13. Fedele L, Bianchi S, Agnoli B, Tozzi L. Urinary tract anomalies associated with unicornuate uterus. J Urol 1996; 155:847-8. 